\title{
THE ROLE OF THE INTEGRATED HEALTH POST IN HEALTH CARE PROVISION FOR CHILDREN UNDER FIVE
}

\author{
Mery Aderita Romaulina', Masyitoh², Afrina Sitohang1, \\ Febi Susanti', Sari Hayuningtyas', Yayah Fazriah' \\ 1)Masters of Public Health, Universitas Indonesia \\ 2)Department Health Policy Administration, Faculty of Public Health, \\ Universitas Indonesia
}

\begin{abstract}
Background: Global evidence shows that building an integrated health system with a strong foundation in primary care can result in important pay offs. It can improve population health outcomes, ensure financial protection to citizens, enhance their experience in accessing healthcare, and provide improved value for money to the system. The purpose of this study was to determine the role of the integrated health post in health care provision for children under five.

Subjects and Method: This was a qualitative study conducted at integrated health post (Posyandu), Jakarta. Key informants included mothers, health cadres, professional health workers, community members, and community leaders. The data were collected by in-depth interview, participant observation, and focus group discussion. Data analysis consisted of data reduction and data display.

Results: The role of health services at the Posyandu has not been optimal, such as anthropometric measurement. This factor is due to the lack of inputs (material, machinery, policies, people and method), inadequate facilities, and less skilled health cadres. In providing health services cadres lack support from the communities. Most informants did not know the health activities for infants and children under five health care services outside the Posyandu schedule.

Conclusion: Health services for infants and children under five have been routinely carried out, but not in accordance with the implementation guidelines. Community health center need to improve the competence of health cadres and collaborate with multi-sector to fix inputs also establish partnerships with private parties.
\end{abstract}

Keywords: integrated service posts, health cadre, children under five

\section{Correspondence:}

Mery Aderita Romaulina. Masters of Public Health, Universitas Indonesia. Email: meryaderita14@gmail.com. Mobile: 081283692693.$$
\text { BACKGROUND }
$$

Globally, there were 5.6 million children under five died, 15,000 every day in 2016. This means that there are still 10 children under five die every minute (WHO, 2017). About $73 \%$ of under-five deaths occur in two regions in
}

2017, WHO Africa (49\%) and WHO Southeast Asia (24\%). Indonesia has made significant progress in reducing child mortality to 25.4 per 1,000 births. Indonesia estimated that 147,00o children under five still die every year, meaning that every minute 
there are still children, who die, with almost half of under-five deaths occurring in the first month after birth (UNICEF). Most of these deaths are related to vaccine preventable diseases, pneumonia, labor complications, in addition to the double burden of diarrhea and malnutrition. Malnutrition is estimated to be associated with 2.7 million child deaths each year or $45 \%$ of all child deaths. The first two years of life are very important because optimal nutrition during this period decreases morbidity and mortality, reduces the risk of chronic diseases, and encourages better overall development. Other health problems of children and toddlers are stunting globally data shows that 155 million children experience dwarf (WHO, 2016).

According to $\mathrm{WHO}$, the stunting gap, the absolute difference between the poorest (48.4\%) and the richest (29\%) is 19.4 percentage points. For the lean, the gap between the poorest (27.2\%) and the richest (13.7\%) stretched 13.5 percentage points. The prevalence of wasting is different from 3.5 percentage points in the quintile and the highest in the poorest quintile (14.1\%) and the lowest in the richest quintile (10.6\%). This means that stunting, thin and wasting children can occur in every child with poor or rich economic conditions and have an impact on the household economy.

Indonesia made a policy about the Indonesia Healthy program to address the health problems of children under five through a family approach by involving the community known as Community-based Health Efforts (UKBM). UKBM is one approach that has been implemented for a long time, one of which is a toddler Posyandu. Posyandu is an integrated service post which is one form of UKBM that is managed and organized from, by, for and with the community in the implementation of health development, to empower the community and provide facilities to the community in obtaining basic health services, especially to accelerate the reduction of maternal mortality and baby.

Community involvement in the management of Posyandu is still not optimal. Posyandu activities increase parents' understanding of the importance of immunization for children and toddlers. Most mothers of toddlers (95.7\%) knew about the meaning of KMS, but they rarely used the information contained in KMS to take actions related to children's health (Ministry of Health, 2013).

The implementation of Posyandu activities should ideally all service posts use a 5-table system to facilitate the provision of services and records, involve community participation in Posyandu cadres and monitor child growth and development by health workers by involving parents.

Saepudin et al. (2017) states that Posyandu has an important role in improving the quality of maternal and child health through the health service process and Posyandu has become a public health information center. Although there are several studies that state that Posyandu is quite effective, there are still contradictory studies, among others, the Aditya study, 2015, which shows that there are limited facilities and infrastructure to support the implementation of Pos- 
yandu, resulting in dissatisfaction with Posyandu users (Aditya, 2015).

Other research shows that Posyandu has not been fully successful in achieving the objectives of implementing Posyandu activities, as seen from not yet fully service coverage indicators have not been reached and found also inadequate facilities and infrastructure (Nainggolan et al., 2014). Several factors related to the implementation of Posyandu include cadre education level, length of time as cadre, cadre position, provision of counseling media, cadre training, cadre training, facilities and infrastructure, involvement of cross-sector roles, provision of information and communication.

\section{SUBJECTS AND METHOD \\ 1. Study Design \\ This was qualitative study conducted at the Nangka Posyandu in Pejuang Sub-District, Medan Satria District, Jakarta.}

\section{Study Informants}

The informants in this study were pregnant women, infants/ toddlers, Posyandu cadres, health workers and the mother of the Team for Driving Family Empowerment and Welfare (TP PKK) head.

\section{Data Analysis}

Data was obtained through in-depth Interview, Focus Group Discussion (FGD) and observation. The results obtained were validated by data triangulation. The data were analyzed by organizing and sorting data into patterns, themes, or categories to be interpreted through three stages, namely data reduction, data display conclusion and verification withdrawal.

\section{RESULTS}

1. Materials

a. Financing

Funding or funding for the implementation of Posyandu comes from selfhelp cadres and cadre leaders, while additional costs come from voluntary contributions from Posyandu visitors. Funds for financing Posyandu are still very lacking. It lacks support from the local neighborhood (RT)/ hamlet (RW) so that the Posyandu has not been able to find a solution to the financing problem.

b. Socialization media

There was no media for counseling at the Posyandu, so visitors to the Posyandu had never seen the counseling media. The outreach media originating from Puskesmas and villages are only used when there are counseling events outside the Posyandu activities.

\section{c. $\mathrm{MCH}$ Handbook}

The MCH Handbook has been integrated with KMS records and contains information about growth and development as well as things that need to be known by health personnel, health casers and pregnant women or mothers of children under five. From the FGD activities, in-depth interviews, and observations made it was known that some informants knew the $\mathrm{MCH}$ handbook and it was important to take them to the Posyandu, the contents of the $\mathrm{MCH}$ handbook were also explained during the visit. Usually cadres or health workers remind to bring $\mathrm{MCH}$ handbook. However, some informants did not know what the $\mathrm{MCH}$ handbook was. 


\section{Machine (Facilities and infra- structure)}

Based on the results of observations, FGDs and interviews with health workers and TP PKK, the basic facilities that were not yet available at the Nangka Posyandu were Information and Education Communication Materials (IEC), iodine capsules, worm medicines. Whereas the facilities that are still lacking or the amount that is not yet in accordance with the needs are chairs for visitors to the Posyandu. The location of the Nangka Posyandu is quite strategic, located opposite the place of worship and near the highway. It can be reached by people by walking for 5-10 minutes.

The building area cannot accommodate all visitors to the Posyandu. Extension activities are carried out at schools located next to the Nangka Posyandu. The implementation of Posyandu is carried out regularly every month with a 5-table system, although it is not in accordance with the stages in its implementation. Cadres are active and have great motivation to provide services to the community, mothers of children under five, toddlers and pregnant women.

\section{Man/ Human Resources}

From the results of the Focus Group Discussion participants' opinions, indepth interviews and observations on the role of Posyandu cadres and motivation as Posyandu cadres, most informants said that active cadres in the Posyandu services implemented 5 steps/ system 5 tables and there was a division of tasks.

The results of observations, cadre skills in conducting weighing have not been owned by all cadres even though there is always a change of duty in the implementation of the Posyandu. This will affect the recording of toddler growth. Research by Hadiyanto et al. (2018) shows that there is a relationship between the knowledge of underweight weighing on precision and accuracy.

As for the Posyandu cadre motivation, information obtained from the FGD and WM results, most of the informants stated that being a cadre is a desire/ encouragement from the heart and has a high commitment to help others to get health services. Based on observation, cadres look active and enthusiastic and understand and carry out their respective tasks.

\section{Method}

The method of implementing Posyan$\mathrm{du}$ is using 5 tables or also called 5 steps. From the FGD activities, in-depth interviews that have been conducted are known that the 5-table system has been applied at the Nangka Posyandu. The 5 -table system consists of registration, weighing, recording, counseling, and service. Cadres can mention 5 steps in implementing Posyandu. From observations, it can be seen that the 5 steps of implementing Posyandu are carried out but not sequentially. Some MCH workshop such as giving PMT toddlers, immunizing toddlers, diphtheria immunization have been carried out at the Posyandu.

DISCUSSION
1. Material
Financing is a source used by Posyan-
du to provide services. The financing
of Posyandu comes from the commu-
nity, namely the contributions of visi-


tors to the Posyandu and voluntary contributions. And there is transport money for each cadre budgeted by the village every month. In accordance with the general guidelines for the implementation of the Posyandu (Ministry of Health of the Republic of Indonesia, 2011), the financing of the implementation of Posyandu comes from the public, the private sector and the government.

Extension media and $\mathrm{MCH}$ handbooks are media for communication of behavior change in family empowerment is an important component, especially to clarify the delivery of messages to avoid misperception. One of the keys to successful communication of behavior change is determined by the quality of the various types of media used. In general, communication media has the strength and function to increase knowledge, motivation, build a positive attitude and clarify behavior or actions that must be done by the target in this case is the mother of children under five and visitors to the Posyandu. However, in its use each type of media has strengths and weaknesses. In connection with that, the media used is not only one type, but various types of media simultaneously or media mix. This is intended to overcome the weaknesses of each type of media used in counseling.

\section{Machine (facilities and infra- structure)}

Facilities and infrastructure are supporting the success of a process carried out in community services to meet expectations. The health center has a role in helping fulfill the services of health facilities and infrastructure as well as supporting technical health guidance. Based on the results of the research through the Focus Group Discussion method in conducting services at the Posyandu, there are basic facilities that must be equipped that services can run optimally.

The results of previous studies by Reihana and Duarsa (2012), stated that the distance from the house to the Posyandu greatly influenced the mother's visit to the Posyandu. The location of a reachable Posyandu will greatly influence the high level of community visits to the Posyandu. Arwinda et al. (2014) showed that the completeness of facilities and infrastructure had an effect on the activeness of the Posyandu, with good facilities the Posyandu activities could take place optimally, both during open Posyandu days and during home visits without experiencing obstacles.

The establishment of the Posyandu is carried out by the headman's decision and the decision letter is in the headman's office. The policy on the implementation of Posyandu has been regulated by the Ministry of Home Affairs Permendagri No.54 of 2007, clearly mentioning the tasks and functions of the Operational Working Group for Coaching Post and Integrated Health Care (Posyandu Pokjanal). Puskesmas has made plans related to Posyandu, but it is not optimal yet, there are still children under five who do not have $\mathrm{MCH}$ handbook, even though the $\mathrm{MCH}$ handbook is mandatory. Coaching has been carried out by the Puskesmas and the head of the PKK RW which should also be carried out by the relevant sectors listed in the pokjanal. Based 
on the observation of the location of the Nangka Posyandu, there are around 3 large companies.

\section{Man (Human Resources)}

Human resources are an important element. Cadres, health workers, TP PKK, sub-district and related sectors are very influential on the active Posyandu. The availability of human resources in this case is 10 cadres as Posyandu implementers.

Health personnel have a mandatory duty to attend when conducting a Posyandu once a month which has the role of guiding cadres in organizing Posyandu, organizing health services and family planning in step 5 , holding health counseling and counseling (Indonesian Ministry of Health, 2011). From the results of the FGD and indepth interviews, it was found that health personnel were present at each Posyandu implementation and provided health services at table 5 such as examining pregnant women and immunization. However, according to most informants, health personnel have not optimally provided guidance and direction to cadres to cadres.

PKK pioneer team played an active role in organizing Posyandu, mobilizing community participation, and counseling both at Posyandu and outside of it as well as completing the data in accordance with the Posyandu information system (Indonesian Ministry of Health, 2011). From the results of the FGD and in-depth interviews, most of the informants answered that the RW head in turn conducted visits to the Posyandu, and tended to be monitoring, not actively involved in the service. In accordance with the research conducted by Sihombing et al. (2015) that the role of village heads, nutrition officers, PKK cadres and mothers influenced the number of visitors to the Posyandu to be high. It can be seen from the data in this Posyandu that coverage of community participation (D/S) was in January 2018, 85.7\%, February 2018, 95.4\%, and in March 2018 it reached 94.9\%.

\section{Method}

At the time of implementation, a minimum cadre of Posyandu is 5 people. This number is in accordance with the guidelines, which refers to the 5 -step system. Activities carried out at each step as well as those responsible for their implementation can be simply described in the following table (General Guidelines for Posyandu Management (Ministry of Health, 2011) but not sequentially because the room is inadequate.

\section{REFERENCE}

Arwinda R, Arifin S, Herawati (2014). Hubungan ketersediaan sarana dengan pelaksanaan Posyandu pada wilayah kerja Puskesmas di Kota Banjarbaru. Jurnal DK, 2.

Dinas Kesehatan Kota Bekasi (2014). Profil Kesehatan Kota Bekasi Tahun 2014. Bekasi: Dinas Kesehatan Kota Bekasi

Hardiyanti R, Jus'at I, Angkasa D (2018). Hubungan lama kerja menjadi kader, pengetahuan, pendidikan, pelatihan dengan presisi dan akurasi hasil penimbangan berat badan balita di Posyandu. Jurnal AcTion: Aceh Nutrition Journal, 3:74-81.

Husniyawati YR (2016). Analisis Pengaruh Motivasi Komitmen dan 
faktor organisasi terhadap kinerja kader Posyandu. Skripsi Fakultas Kesehatan Masyarakat Universitas Airlangga

Ministry of Health RI (2011). Pedoman umum pengelolaan Posyandu. Jakarta: Kementerian Kesehatan.

Ministry of Health RI (2015). Modul pelatihan bagi pelatih pengelola komunikasi perubahan perilaku dalam pemberdayaan keluarga di puskesmas. Jakarta: Kementerian Kesehatan.

Ministry of Health RI (2018). Profil Kesehatan Indonesia Tahun 2017: Data dan Informasi. Jakarta: Kementerian Kesehatan.

Puskesmas Pejuang (2017). Profil Kesehatan Puskesmas Pejuang Tahun 2017. Bekasi: Puskesmas Pejuang.

Reihana, Susila AB (2012). Faktorfaktor yang berhubungan dengan partisipasi Ibu menimbang balita ke Posyandu. Jurnal Kedokteran Yarsi, 20(3):154-155.

Sihombing K, Kandarina BJ, Istiti, Sumarni (2015). Peran lurah, petugas kesehatan dan Kader dalam partisipasi ibu balita ke Posyandu di wilayah cakupan $\mathrm{D} / \mathrm{S}$ terendah dan tertinggi di Kota Jambi. Jurnal Gizi dan Dietetik Indonesia, 3(2):87-97. UNICEF (2018). The Early Years. Available from: http://www.unicef.org/indonesia/children_26445.html

WHO (2009). WHO Guide to Identifying The Economic Consequences of Disease and Injury. Department of Health Systems financing Health Systems and Services. Geneva: WHO.

WHO (2018). Global Health Observatory Data. Retrieved from: http://www.who.int/gho/child_ health/en/. 